Fordham Law School

FLASH: The Fordham Law Archive of Scholarship and History

Faculty Scholarship

2012

\title{
The Flood of U.S. Lawyers: Natural Fluctuation or Professional Climate Change?
}

Bruce A. Green

Fordham University School of Law, bgreen@law.fordham.edu

Follow this and additional works at: https://ir.lawnet.fordham.edu/faculty_scholarship

Part of the Legal Profession Commons

\section{Recommended Citation}

Bruce A. Green, The Flood of U.S. Lawyers: Natural Fluctuation or Professional Climate Change?, 19 Int'I J. Legal Prof. 193 (2012)

Available at: https://ir.lawnet.fordham.edu/faculty_scholarship/629

This Article is brought to you for free and open access by FLASH: The Fordham Law Archive of Scholarship and History. It has been accepted for inclusion in Faculty Scholarship by an authorized administrator of FLASH: The Fordham Law Archive of Scholarship and History. For more information, please contact tmelnick@law.fordham.edu. 


\title{
The flood of US lawyers: natural fluctuation or professional climate change?
}

\author{
BRUCE A. GREeN \\ Fordham University School of Law, New York, USA
}

\begin{abstract}
This paper considers how US courts, which regulate the US legal profession, should respond to the perceived excess of lawyers (i.e. to the lack of adequate employment opportunities for lawyers). It begins by summarizing the courts' regulatory role. It then situates the contemporary flood-of-lawyers problem in the unavailability of well-paid legal work, not in the absence of a need for lawyers' services: many people need lawyers, but they cannot afford them. Next, the paper explores whether the problem is simply a product of natural economic fluctuation which will be solved naturally, particularly if potential law school applicants become better informed, and suggests that the problem is at least in part an artificial product of professional regulation. Finally, the paper explores possible regulatory solutions, concluding with the possibility of eliminating lawyers who perform adequate but lowest-quality work. It concludes that using regulatory means of lowering the tide of lawyers is not viable.
\end{abstract}

Many believe that there are too many US lawyers, by which they mean that US lawyers are competing for too few paying clients and too few jobs that require or utilize a law license (Dolin, 2007; Greenbaum, 2010; Tamanaha, 2012). Some unemployed lawyers recently sued the US law schools from which they graduated, blaming the 'nationwide glut' of lawyers on law schools' expansion of admissions while legal employment opportunities decreased (Shaer, 2012). Other possible causes of the perceived overabundance of lawyers include that too many college graduates are attending law school for lack of better career alternatives, out of idealized expectations about their career prospects, or lured by the easy availability of federal loans for tuition (Podgers, 2011; Tamanaha, 2012), and that economic stagnation, technology, and global competition (including outsourcing) have reduced the need for US lawyers among clients who can afford legal services (Henderson \& Zahorsky, 2011). Whatever the causes, this situation raises a regulatory question: If there is a flood of US lawyers, can and should courts do anything through their oversight of lawyer

Address for correspondence: Professor Bruce A. Green JD, Louis Stein Chair, Fordham University School of Law, 140 W. 62nd Street, New York 10023, USA. Email: bgreen@law.fordham.edu 
licensing and discipline to stem the tide? This paper explores this question, concluding with an examination of what most would see as a 'modest proposal' : that US courts respond to the excess of lawyers by de-licensing the least capable ones.

\section{Background: regulation of the US bar - quality and quantity}

Unlike in many other countries, regulation of the bar in the United States is principally in the hands of state judiciaries. State courts have authority to admit new applicants to practice law, establish standards of professional conduct, and discipline or disbar lawyers who engage in professional misconduct or cease to be competent. Most state courts delegate significant aspects of these responsibilities to professional staff or to volunteer lawyers.

The most expensive entry requirements for admission to the US bar are an undergraduate degree and a law degree. Although a handful of states still hold out the possibility of 'reading for the bar,' virtually no applicants take advantage of this alternative (Sloan, 2011a). And while law schools may admit applicants without an undergraduate degree, this rarely occurs. Most state judiciaries require graduation from an American Bar Association (ABA)-accredited law school, thereby leaving it to the ABA to determine the length of law school (generally, 3 years for full-time students) and the curricular and other requirements. The cost of a legal education has burgeoned in the past few decades; although the causes are disputed, among those cited have been pressures to provide clinical training, smaller classes, more individualized education, and other expensive forms of curricular and noncurricular assistance in response to accreditation requirements, competition for rankings, and complaints from law firms and clients that law students are inadequately prepared for practice (ABA, 2012b; Bourne, 2012; Tamanaha, 2012; US Government Accountability Office, 2009).

After graduating from law school, applicants are required to pass a written bar examination, for which law school typically does not completely prepare them. Bar examinations are administered semiannually. Most states administer standardized written tests generated by the National Conference of Bar Examiners based on federal or nationally consistent law. The tests mainly assess knowledge of the substantive and procedural law and the ability to apply the law to factual scenarios. Some states attempt to test certain lawyering skills as well. Applicants generally devote weeks of study to the examination, purchase a bar review course or written study materials, and pay an examination fee; however, these expenditures of time and money ordinarily pale in comparison to the length and cost of a formal undergraduate and legal education. ${ }^{2}$ Most law graduates who sit for the bar examination receive a qualifying score (National Conference of Bar Examiners, 2012) and are then licensed to practice law, but a significant minority of each state's applicants fail the examination, in which case they may retake it at a later time.

Over time, the gap has grown between the abilities of newly admitted lawyers and the necessary skills and knowledge to practice law. But the assumption that graduates' ill-preparedness is attributable to the deficiency of legal education seems doubtful. The expansion of legal writing, simulation and clinical courses, while running up 
the cost of a legal education, probably makes graduates better prepared than in the past. The gap nevertheless has expanded because law has become more complex and highly specialized over time (Morgan, 2010) and because there is a lower tolerance for learning at clients' expense. ${ }^{3}$

Once admitted to practice, lawyers have no significant regulatory requirements to maintain their licenses other than to refrain from professional misconduct. States have no postgraduate apprenticeship or articling requirement for new lawyers. ${ }^{4}$ Most states require lawyers to pay periodic licensing fees and take a modest number of hours of Continuing Legal Education courses of unproven utility (Grigg, 1998). No state requires lawyers to demonstrate continued competence or proficiency in their areas of concentration as a condition of retaining a law license. As far as I know, no state has ever seriously considered adopting a certification or relicensing requirement.

A law license provides relatively exclusive authority to perform the full array of legal work. The legal profession's monopoly is given legal effect by laws forbidding the "unauthorized practice of law" (UPL; ABA, 2012a). These laws generally prohibit nonlawyers from representing clients in court, giving clients legal advice, or drafting legal documents for clients. A law license in the United States is a general license to hold oneself out as a lawyer and to perform virtually any or all of the work reserved to lawyers. The profession is not formally divided into particular areas of practice, and lawyers may practice in multiple areas or move freely between different practice areas and settings. Although some professional organizations certify lawyers as specialists in certain areas of law, state courts do not require such certifications as a condition of practicing in particularly complex areas. Lawyers are expected, as a matter of self-restraint and the professional duty of competence, to refrain from offering services that they are unequipped to provide. New lawyers may perform relatively simply legal tasks and/or work under supervision or in collaboration with more experienced lawyers while obtaining on-the-job training necessary to perform more demanding work.

In theory, and subject to constitutional or other legal restrictions on their authority, the US regulatory process affords courts various opportunities to regulate the size of the bar directly or indirectly. Most directly, courts or the admissions authorities to whom they delegate responsibility might keep numbers down by restricting entry to the profession or by delicensing some number of admitted lawyers. Indirectly, they may limit the number of lawyers by establishing more difficult or expensive eligibility or licensing requirements - e.g. a requirement of even lengthier and more expensive legal education as a prerequisite for admission, or high licensing fees or other onerous requirements to retain a license.

Since the late nineteenth century, the requirements for US law practice have evolved, but never expressly with an eye toward limiting the number of lawyers (Jarvis, 1996). The express aim of the court-supervised admission and regulatory processes has been to maintain the quality of the bar, not the quantity of practitioners. Of course, the legal profession's entry requirements in a given jurisdiction have an impact, to a greater or lesser degree, on the extent of the profession's monopoly (Abel, 1996). In the United States, the attorney admissions requirements coupled with UPL provisions have the effect of limiting the size of the legal profession. But 
courts have never acknowledged that a purpose of admissions requirements is to maintain the economic viability of law practice by maintaining an artificial limit on the bar's size, and the steadily increasing number of lawyers indicates that this is not a substantial unacknowledged motivation.

Even if by happenstance, however, regulatory requirements and market forces do establish increasingly significant barriers to entering the legal profession and maintaining a law practice. In the early twentieth century, the legal profession in the United States was viewed as a vehicle for social mobility for lower-income individuals because entry was relatively inexpensive and little capital was required to establish a law practice (Auerbach, 1976). Today, however, it is questionable whether law will remain an affordable path to social mobility other than for those admitted to toptier law schools or who receive scholarships to attend law school (Segal, 2011b). In 2012, many students borrow more than $\$ 100,000$ to attend private law schools (Tamanaha, 2012). If a student performs reasonably well at one of the most prestigious law schools or exceptionally well at a lower-ranked one, he or she will likely be able to enter a mid-size or large law firm, earn a starting salary in excess of $\$ 100,000$, and pay down student loans while gaining useful experience and contacts. If not, starting salaries (or fees from clients if an entrepreneurial graduate strikes out on his or her own in a solo or small firm practice) may be too low to make loan repayments feasible. Despite efforts to make the legal profession more accessible, the result may be to make the pool of applicants increasingly less diverse.

\section{Is there a flood of lawyers?}

Are there too many lawyers in the United States? The answer depends on what one means by the question. In the mid- to late-nineteenth century, the complaint might have been that there was a flood of incompetent and unethical lawyers because of the ease of entry (MacCrate Report, 1992). That is the complaint that prompted the establishment of the ABA and state bars beginning in the 1870s. The establishment of higher barriers to entry in the early twentieth century, while reducing competition, did not guarantee lawyers a livelihood, however. In the 1930s, at least until the New Deal era, even top graduates of top law schools had difficulty landing employment in the law. ${ }^{5}$

At a more recent point in history, the complaint about the excess of lawyers reflected a perception not that there was too little available legal work but that there was too much. That we appeared to have so many more lawyers per capita in the United States than in other industrialized countries was said to be symptomatic of an over-regulated, overly litigious society. ${ }^{6,7}$ The complaint about the flood of lawyers became a trope of opponents of environmental, safety, and business regulation and proponents of tort reform, among others. However, the charge that the legal profession is overpopulated has become less prominent in the rhetoric of those who complain that laws and lawsuits are bad for business. ${ }^{8}$

Since the recent economic downturn, lawyers and law students in the United States have taken up the charge, albeit with a different meaning. Their complaint is that there is not enough legal work to justify the number of lawyers (Segal, 2011b). 
At first, one might be skeptical, given the common understanding that there are significant unmet legal needs. The legal profession presumes that those with legal problems are best served by obtaining legal assistance, because it is difficult for individuals to navigate the law and legal processes on their own. Most low- and middle-income individuals with legal problems, such as tenants in eviction proceedings, individuals seeking divorces, and applicants for government benefits, are unrepresented (Rhode, 2000, 2005). This might suggest that there are not too many lawyers but too few.

A trio of scholars - Clifford Wilson, Robert Crandall, and Vikram Maheshri recently made this argument (Winston \& Crandall, 2011, pp. 82-94). Their proposed solution to the unmet need for legal assistance is not to reduce the professional ranks but to deregulate entry into the legal profession in order to swell the ranks. Eliminating or liberalizing UPL restrictions would allow individuals to provide legal services without the necessity of an expensive, three-year legal education. For less expensively trained legal professionals, representing low-income individuals would presumably be economically viable. Increased competition would, thus, expand access to legal services. Other countries offer models for licensing and regulating paralegals or other categories of legal professionals to perform law-related work, including certain legal work that US lawyers now monopolize, but for which quicker, inexpensive legal training will suffice. However, the organized bar in the US has traditionally defended both the idea of a unified profession and the professional monopoly (Green, 2009; MacCrate Report, 1992).

Implicit in the idea of deregulating the admission process is recognition that, under the current regulatory regime, which demands that lawyers be highly educated, laws of supply and demand will not reduce legal fees enough to make lawyers more broadly accessible to lower- and middle-income individuals. ${ }^{9}$ Legal services are not a commodity that a seller has an economic incentive to unload at the lowest price. Lawyers' stock in trade is their time, and if they cannot use their time profitably enough by rendering legal assistance, they will use their time in business or some other pursuit. The obvious ways to make legal services more accessible to low- and middle-income clients, other than by subsidizing them, is to lower the educational barriers to entry and open professional practice to individuals who cannot use their time more profitably. This would seem to be at odds, however, with courts' regulatory objectives, particularly if one assumes that the extensiveness of legal training reflects the complexity of law practice.

The contemporary flood-of-lawyers complaint, then, is not that there are too few clients but that there are too few well-paying clients and well-paying legal positions to support the number of highly qualified lawyers produced by US law schools under the current lengthy and expensive licensing processes. At least for new lawyers, complaints about the number of lawyers are implicit complaints about the cost of becoming a lawyer: If one could become a lawyer without the costs of tuition, living expenses, and deferred earnings, and without having to repay debt incurred by many young lawyers to finance seven years of higher education, more lawyers could afford to serve the low- and middle-income client population and, in any event, fewer would 
have cause to complain about the scarcity of career and employment opportunities in the law. ${ }^{10}$

As so understood, the complaint that there are too many US lawyers seems undeniable. If there were doubt, testimony would be offered by the many recent US law school graduates who cannot find full-time legal positions or who cannot find any entry-level positions in the legal field, ${ }^{11}$ by the many unemployed mid-level lawyers who cannot find new positions, and by solo and small-firm private practitioners struggling to keep their heads above water.

\section{Natural fluctuation?}

One might be tempted to view the flood of lawyers as a product of natural fluctuation that will eventually be resolved naturally: Sometimes there will be too many lawyers for available legal work, sometimes too few, and the market will eventually take care of the problem (Sander \& Williams, 1989). The need for lawyers will vary at any given time based on various factors, including the level of economic activity, the nature and extent of regulation, and the availability of alternatives to lawyers such as the use of paralegals or technology (ABA, 1973). That seems to be the lesson of the post-World War II decades, during which the number of US lawyers and law schools increased explosively, despite occasional 'market gluts' during temporary economic downturns (MacCrate Report, 1992; Bickerton, 2003).

That is evidently the organized bar's assumption in reaction to claims, including legal claims, by recent law school graduates who assert that they were induced to attend law school by misleadingly rosy projections about the availability of wellpaying jobs (Shaer, 2012; Segal, 2012). Instead of promoting regulatory solutions, such as higher barriers to entry into the legal profession (which might well incur the opposition of antitrust authorities in any event), the bar has promoted market solutions. It has called on law schools and other institutions of the legal profession to provide more, and more accurate, information, to enable the market to work more efficiently (Tamanaha, 2012). Presumably, the expectation is that college graduates will then make better informed choices about whether to attend law school in pursuit of a legal career, and more will make the economically intelligent choice not to seek entry into the legal profession, thereby gradually bringing the number of lawyers seeking paying work into alignment with the number of clients seeking to retain lawyers.

One might question, however, whether the flood of lawyers is primarily a problem of inefficient markets and asymmetrical information that can be solved by greater candor. The theory is not necessarily supported by recent experience: Since the most recent economic downturn, there has been abundant, accessible information in the popular and professional press about the scarcity of legal employment prospects, but interest in attending law school, although sharply diminishing, has remained high (Segal, 2012). This may be explained, for example, by the unrealism or wishfulness of college graduates or the absence of alternative employment. Either way, it does not ensure a natural thinning of ranks. 
Moreover, the flood of lawyers is at least in significant part a creature of lawyer regulation. There is nothing free about either the market for law licenses or the market for legal services. As previously discussed, both are heavily regulated. Those needing legal services are limited to hiring lawyers or representing themselves. The requirements of undergraduate and graduate education along with bar passage make lawyers expensive. The regulatory premise is that consumers of legal services lack the necessary sophistication and information to distinguish between competent and incompetent legal practitioners, and, therefore, for the protection of the public, the licensing and disciplinary processes and the UPL laws must limit the pool of legal practitioners to those who are competent to practice.

When there seemed to be a high demand for paid legal services, universities and entrepreneurs decided to establish law schools that exploited the lawyer monopoly created by courts as regulators. ${ }^{12}$ Once a university opens a law school, it is unlikely to close it, even if the quality of the applicant pool decreases. Having fixed costs, law schools have a disincentive to reduce the size of their entering classes too drastically, although many have begun enrolling smaller classes. As potential consumers of legal education become savvier and the number of applications drops, law schools may enroll less capable applicants in order to meet their costs.

An alternative market-driven answer is that competition among lawyers for limited numbers of clients and positions is good, or at least tolerable, because clients and employers will retain the best lawyers and the least competent will be forced to leave law practice for other labor. The problem with this theory is that, from the legal profession's perspective, clients (and especially unsophisticated ones) cannot effectively distinguish good lawyers from bad ones (Wilkins, 1992). That is both because clients lack the specialized knowledge adequately to judge the quality of lawyers work and because client confidentiality obligations preclude lawyers from giving prospective clients enough information on which to make effective assessments. Were it otherwise, courts would not perceive a need to protect the public by denying admission to applicants who, based on a bar examination, appear to lack the requisite competence to practice law. Just as clients cannot distinguish the incompetent from the competent, they cannot distinguish the mediocre from the proficient. The flood of lawyers may trigger an unseemly competition over clients but not necessarily generate the benefits to clients that are already expected to accrue from wider choice.

\section{Regulatory responses: stemming the tide}

\section{Upstream solutions}

If courts perceive that there are too many lawyers and that the public is poorly served as a result, they can reduce the number of lawyers in any of several ways. The most obvious possibility would be to raise the floodgates at the point of entry by admitting fewer applicants to the bar. This may happen naturally if the passing grade on the bar examination is kept steady in absolute terms, so that as much proficiency on the part of applicants is demanded now as several years ago. If the size and quality of the lawschool applicant pool drops as more college graduates perceive a law degree to be a 
bad investment, graduates might be expected to perform less well than their predecessors (Segal, 2012). But there are no guarantees that test-taking ability will decline relative to the quality of the applicant pool. Law schools may respond to the problem by placing more emphasis on preparing its students for the bar examination, thereby enabling graduates who are less well prepared for actual practice to perform as well as their predecessors on the exam.

An alternative for courts and bar examiners under their aegis is to require higher bar exam scores in relative terms. Artificially reducing the percentage of admitted lawyers in this way can be justified by the need to preserve the quality of the bar. At least in theory, licensing a steady number and percentage of law-school graduates annually, even if admitted law students' credentials decrease, would diminish the quality of the bar, thereby undermining the core regulatory objective of preserving professional competence. The question can be framed not as whether to reduce the number of admitted lawyers in order to reduce competition among lawyers for the sake of lawyers' economic wellbeing, but whether to reduce the number of admitted lawyers in order to protect the public from incompetent ones.

One problem with this approach is that it requires acknowledging the inadequacy of the bar examination and a presumption that, even if applicants are performing as well as predecessors admitted to the bar in the past, they are still less qualified as demonstrated by LSATs and college grade point averages. Besides being unsubstantiated, the presumption would call the legitimacy of the bar admission process into question.

A related problem is that the bar examination is, at best, just a rough measure of aptitude. It is not a test of whether graduates can already practice law; many who pass are incapable of doing so. Nor is the exam a proven or absolute predictor of one's future ability to become competent in one's future area of legal practice. Therefore, it seems unfair and arbitrary to deny admission to those who may score lower than others on an examination but seem to be sufficiently capable in absolute terms to embark on a legal career, and especially unfair given the time and expense of a legal education. The exam focuses primarily on legal knowledge and analytic and writing abilities, but law practice requires many other capabilities (Maguire Shultz \& Zedeck, 2009). ${ }^{13}$ Those who score lower on the bar exam may have capabilities that the exam does not test and might go on to become better and more successful lawyers. Or they may limit themselves to areas of practice that draw on their capabilities and that others are uninterested in pursuing. The public might be better served by having a larger number of graduates compete rather than limiting the number of new lawyers in a manner that may not correspond to ultimate ability to practice proficiently in one's chosen area. ${ }^{14}$

One can anticipate other objections. As it is, bar examinations are subject to varied and frequent criticism. ${ }^{15}$ If bar passage rates became significantly lower, law schools would object because a legal education would become an even riskier and less attractive option; paradoxically, the result would be to further discourage qualified applicants. Lowering the bar passage rate might also turn out to affect minorities and low-income applicants disproportionately, thereby further thwarting efforts to diversify the legal profession and to provide opportunities for social mobility. ${ }^{16}$ As 
Robert McKay noted thirty years ago, a time when applicants' qualifications were improving, limiting the growth of the legal profession by reducing the bar passage rate seems unlikely and undesirable "in a free society in which the legal profession has traditionally insisted upon open access to the profession for all qualified applicants" (McKay, 1984, pp. 45-46).

In any event, it seems unlikely that courts could reduce the number of newly admitted lawyers enough to make a noticeable impact on the level of competition for legal work. Certainly, the impact would not be noticeable broadly across the profession, but would be concentrated in the area of entry-level employment. Admitting fewer lawyers would do nothing for mid-level and senior lawyers competing for too few clients or employment opportunities.

An alternative is for courts (themselves or through the ABA) to erect barriers even further upstream, that is, by establishing more onerous requirements for admission to, or graduation from, law school. ${ }^{17}$ California offers one model in its regulation of non-ABA-accredited in-state law schools. Students in these schools are required to pass a standardized examination midway through law school in order to continue to graduation and sit for the ordinary bar examination (Jarvis, 1996). Courts could conceivably reduce the number of new lawyers by requiring all law students to pass such an examination at an intermediate point. Arguably, such a requirement would be a more humane alternative in one respect: it would reduce the number of students who pay for a full three years of law school before being denied admission. But it would also prejudice law schools that would have to forgo tuition, increase the anxiety of a legal education, and eliminate some students who were poor test-takers but potentially excellent lawyers.

\section{Downstream solution}

The less obvious, but perhaps theoretically most attractive, alternative, is to erect barriers downstream - that is, to remove the licenses from the least capable practicing lawyers by requiring periodic re-certification and denying it to those who perform their work least well. This alternative is attractive in theory because it eliminates the need to make distinctions among individuals who have never practiced law based on an examination that does not perfectly predict whether one will later become a good lawyer. Instead, a re-certification requirement would focus on whether one is in fact a good lawyer. ${ }^{18}$

Lawyers might be providing below average services for any number of reasons. Some never developed the skills and knowledge to perform legal work well. Some engage in particular legal work for which they lack the requisite skills and knowledge. Some are fully capable of good work but are unmotivated, distracted or over-committed. Some were once capable but have failed to keep up with changes in the law or in modes of practice. From the public's perspective, it may not matter why a lawyer is rendering mediocre or poor work. If it is possible for courts to identify the least capable lawyers, and there are more lawyers than work to support them, the public would presumably be served by delicensing those who perform most poorly, 
thereby protecting clients who are themselves incapable of making reliable qualitative distinctions among lawyers.

Among the advantages to this approach is that it could be directed at lawyers in all practice settings, not just those seeking entry-level positions. And if courts were aggressive enough, they could entirely eliminate the perceived glut of lawyers, thereby ensuring the economic viability of legal careers for those better lawyers who remained. It might be argued that courts should not be in the business of regulating competition among lawyers, but this could be characterized as an incidental byproduct of efforts to maintain the quality of the bar.

The periodic re-certification of lawyers would not be a professional anomaly (Barnard, 2001). Doctors in certain specialties or subspecialties must be periodically re-certified. ${ }^{19}$ Some boards require doctors to demonstrate improvement and professional growth not just maintenance of their professional skills. Commercial airline pilots must also demonstrate their ability periodically. Every six months, some pilots must complete a flight with an Federal Aviation Administration (FAA)certified test rider who is specifically trained to evaluate a pilot's capabilities and ensure that their knowledge of the flight systems is current.

Models for evaluating practitioners already exist in the legal profession. For example, in New York City, membership on a panel of the Legal Referral Service requires a demonstration of experience and capability in one's area of practice. Applicants are interviewed by lawyers who work in the same area and applicants' written work is reviewed. Later, clients who are referred to a panelist are surveyed, and client complaints are investigated. If complaints are found to be justified, panel members can be removed. Other models exist with regard to lawyers seeking judgeships (and similarly in respect of sitting judges seeking new appointments). Selection and nominating committees and bar associations in various jurisdictions evaluate whether individuals are qualified to serve as judges typically based upon interviews of the candidates and of others familiar with their work and reviews of their work product.

Most likely, a proposal that, to raise the general quality of the US bar, a percentage of US lawyers should be required to surrender their law licenses, even though they are performing within the professional standard of competence, would be regarded as facetious. The bar would dismiss such a requirement without serious consideration on the grounds that it is at once anti-competitive and unfair to consumers who have an interest in choice and, at the same time, unfair to lawyers who have a stake in continuing to pursue their chosen careers.

Even if one agreed that a re-certification requirement made sense in theory, there would be convincing practical objections based on the difficulty and cost of devising fair and reliable methods for ascertaining the quality of lawyers' work. Lawyers' work varies enormously. No written test or battery of written tests could reliably gauge the actual quality of their work. It would be necessary for someone actually to examine lawyers' work. Reviewing written work would not be enough, since much of a lawyer's work may consist of counseling, negotiating, oral advocacy or other unwritten work. It would be necessary for examiners to observe lawyers at work for an extended period of time in order to obtain a sufficient basis for evaluation. The observations 
would encroach on attorney-client relationships and confidentiality, however. ${ }^{20}$ In addition, because law practice varies so greatly from lawyer to lawyer, an examiner would probably have to work in the same field as the lawyer to be capable of assessing the work that he or she observed. It might prove difficult to find examiners in all areas of practice whose ability to assess a particular lawyer's work is credible. Even some acknowledged masters might be viewed as politically or culturally biased or as incapable of evaluating competitors impartially and objectively. ${ }^{21}$ In the end, even the best evaluations may be imperfect. For example, generally indifferent lawyers may be more careful when they know they are being observed. There are more than a million US lawyers. Periodically examining them would be a huge and costly endeavor, even if enough lawyers with the requisite experience, integrity, objectivity and evaluative ability could be found to examine them all. From the perspective of maintaining professional competence, few would be convinced that the benefits justify the cost.

Moreover, objections based on unfairness to lawyers and consumers have some legitimacy. Most lawyers would consider the re-certification process burdensome (although it might provide a beneficial learning opportunity and an incentive to keep one's skills and knowledge current). Lawyers who lost their livelihoods (or worried about the possibility) would perceive the re-certification requirement to be harsh and unfair. These lawyers would not necessarily be providing incompetent or neglectful services in absolute terms. The incompetent are presumably removed via the ordinary disciplinary process following client complaints. Rather, the lawyers who lost their livelihood - after having invested substantial time and money into pursuing the legal profession - might be individuals who were competent but simply below average. Arguably, having invested their lives in the law, below-average lawyers should be allowed to continue. It might also be argued that clients should have the option of retaining lawyers whose performance is in some respects below average, because the lawyers may be valued in other respects: for example, they may inspire confidence, provide comfort, or have particular knowledge of the client or the client's work.

\section{Conclusion}

The perceived flood of US lawyers is, in part, a product of the regulatory process, which makes law practice attractive and lucrative for some by excluding nonlawyers and demanding high qualifications. But it seems unlikely that courts will employ regulatory measures to reverse the tide. The more effective a measure would seem to be, the more implausible or impractical it will seem; and theoretically the most effective, a re-certification requirement which would raise the level of professional practice while stemming the tide of lawyers, seems the least viable. That may say something about the US legal profession and its regulatory process. Although professional regulation has been a source of pride for the legal profession for more than a century, its emphasis has been on eliminating unethical and dangerous lawyers, not on enhancing the quality of practice. This is not necessarily to say, however, that the profession is indifferent to quality and to whether and how lawyers develop after they are admitted to practice. It may simply be that the US legal profession has sufficient, if not absolute, 
confidence in natural economic forces to address both the quality and the quantity of lawyers.

\section{Notes}

[1] This would be perceived as a 'modest proposal' at least in the sense in which the term was used by Swift (1729), when he proposed satirically that poor Irish families reduce their burdens by selling their children as food for the well-to-do English.

[2] Bar examinations have been criticized on multiple grounds, including that they disadvantage those who cannot afford a bar review course and that they place a premium on memorization (Jarvis, 1996).

[3] Legal academia in the United States is a lightning rod for dissatisfaction, and many of the complaints are unsubstantiated if not contradictory. For example, the assertion that US law schools should do a better job of preparing students to practice immediately upon being licensed is at odds with complaints about the cost of legal education and, especially, the suggestion that to control cost, law school should be reduced from three years to two (Segal, 2011a).

[4] Delaware requires five months of supervised law practice, which may be undertaken while in law school (Del. Sup. Ct. Rules, R. 52(a)(8)). Vermont requires three months of supervised law practice, which, likewise, may be undertaken while in law school (Vt. Sup. Ct. Rules of Admission, § 6(i)2).

[5] The autobiography of Lawrence Walsh, a future federal judge who struggled academically at Columbia Law School, discussed the difficulty of finding legal employment in the early 1930s, even for his classmates who were editors of the law review (Walsh, 2003).

[6] In 2004, Japan reportedly had one lawyer for every 6,305 people, while the United States had one lawyer for every 186 people (Nakazato et al., 2006).

[7] Twenty years ago, Chief Justice Warren E. Burger observed that "our society is drowning in litigation" and that the "view that there are too many lawyers is widely held by other intelligent laymen, as well as by many leaders of the bar" (Cross, 1992). "Many [California lawyers polled in 1992] agreed that the rising tide of lawsuits stems directly from the growth of the legal profession, whose membership has more than tripled in the past four decades. Nearly half of the poll's respondents favor limiting the number of new lawyers admitted to the bar" (Editorial, 1992).

[8] Another occasional criticism is that the legal profession draws talented individuals away from areas of greater social good such as medicine and engineering (Cross, 1992).

[9] It is also questionable whether the overabundance of lawyers will have a substantial impact on legal fees at the high end, given the highly specialized nature of corporate law practice (Hadfield, 2000).

[10] The increasing difficulty for many US law graduates of recouping the cost of higher education through a career in law practice is now well recognized (Segal, 2011b).

[11] Many law graduates cannot find legal employment and many others "are relegated to jobs as temporary, part-time or contract lawyers, or other work unworthy of their degrees" (Harper, 2011).

[12] This was allegedly motivated in part by the role of "[1] aw schools [as] profit centers, paying overhead and subsidizing programs far from the world of the 1Ls" (Press, 2011).

[13] This is somewhat less true than it was before most states adopted the Multistate Performance Test, which is produced by the National Conference of Bar Examiners to measure certain fundamental lawyering skills. Because this is a written test, however, it is limited in the number of skills it can measure and its capacity to measure those skills.

[14] Lowering the bar passage rate would also seem to be unfair to lower-performing graduates who, though perhaps uncompetitive for legal employment, could pursue other career opportunities more effectively with a law license than merely with a law degree. The law license has often been regarded as a professional credential of significant value even for those who do not intend to, or cannot, achieve a career in the law. It seems harsh to deny bar admission to individuals who seem to have the capacity to become competent lawyers, based on the highly fallible prediction that they will be less capable than others, when the market might steer them away from legal employment in any event. 
[15] The bar examination has been said to overemphasize memorization, and therefore not adequately measure one's qualifications to practice law. Curcio (2002, p. 363) criticizes the bar exam as "over-inclusive, allowing those with a very narrow range of skills to obtain a law license ... [and] under-inclusive by testing a very narrow range of skills in a way that is unrelated to the practice of law."

[16] As it is now, many believe that the admissions process disadvantages minorities (Sloan 2011b; Adams 2008).

[17] Amar and Ayres (2011) have suggested that, alternatively, law schools could offer low-performing students incentives to drop out.

[18] An alternative, but less sweeping, approach would be for disciplinary agencies to review the quality of lawyers' work generally when questions of competence are raised in an individual case. At present, disciplinary authorities do not consider whether a lawyer's neglect or negligence is generally symptomatic of inferior work. "The enforcement of competence in disciplinary cases has looked for proof of incompetence only to individual instances of charged neglect. Courts do not permit disciplinary agencies to engage in general appraisals of the qualifications of an admitted lawyer to practice law. As a result, only relatively blatant cases of incompetence are selected for disciplinary prosecution, and they often appear in isolation from the rest of the lawyer's practice, which may also be infected with incompetence, but of an unreported or milder variety" (Wolfram, 1986, pp. 190-191).

[19] Although doctors do not need to be recertified to maintain their medical licenses, many do need to be re-certified to maintain their status as board accredited. Although passage rates are high for both initial certification and re-certification, the examinations provide an incentive for lawyers to continue training and demonstrate professional growth and development (Federation of State Medical Boards, 2012).

[20] The profession puts a premium on lawyer-client confidentiality. Clients might be reluctant to share information or communicate with their lawyers if they knew the work was being reviewed.

[21] Many areas of legal practice are very difficult to judge objectively. There are no set criteria as to what makes a good lawyer. This means that there is substantial room for bias to creep into an evaluation. Practicing lawyers evaluating their competitors are particularly likely to be perceived as biased. Especially in challenging economic times, lawyers would have a perceived interest in limiting the possible competition in their field.

\section{References}

Abel, R.L. (1996) England and Wales: a comparison of the professional projects of barristers and solicitors, in: R. Label \& P.S.C. Lewis (Eds) Lawyers in Society an Overview (Berkeley, CA, University of California Press), pp. 39-92.

Adams, E.A. (2008) ABA approves bar pass standards for accreditation, American Bar Association fournal, 11 February. Available at: http://www.abajournal.com/news/article/aba_approves_bar_pass_standards/, accessed 23 February 2013.

Amar, A.R. \& Ayres, I. (2011) Paying law students to quit law school, Slate, 18 November. Available at: http://www.slate.com/articles/news_and_politics/jurisprudence/2011/11/law_schools_should_pay_ students_to_quit_html, accessed 26 June 2012.

American Bar Association (1973) Report of the ABA Special Committee on Professional Utilization (Chicago, American Bar Association).

American Bar Association (2012a) ABA Model Rules of Professional Conduct, Rule 5.5, Available at: http:// www.americanbar.org/groups/professional_responsibility/publications/model_rules_of_professional_ conduct/rule_5_5_unauthorized_practice_of_law_multijurisdictional_practice_of_law.html, accessed 26 June 2012.

American Bar Association (2012b) Frequently Asked Questions: Frequently Asked Questions- Accreditation Process, Available at: http://www.americanbar.org/groups/legal_education/resources/frequently_asked_ questions.html, accessed 16 March 2012. 
Auerbach, J.S. (1976) Unequal fustice: Lawyers and Social Change in Modern America (New York, Oxford University Press).

Barnard, J.W. (2001) Renewable bar admission: a template for making "professionalism" real, fournal of the Legal Profession, 25, pp. 1-73.

Bickerton, B.A. (2003) The sky is falling law firm layoffs in a bad economy, Boston Bar fournal, 47(1), pp. 19-20.

Bourne, R.W. (2012) The coming crash in legal education: how we got here, and where we go now, Creighton Law Review, 45, pp. 651-697.

Cross, F.B. (1992) The first thing we do, let's kill all the economists: an empirical evaluation of the effect of lawyers on the United States economy and political system, Texas Law Review, 7(645).

Curcio, A. (2002) A better bar: why and how the existing bar exam should change, Nebraska Law Review, 81, pp. 363-423.

Dolin, J.M. (2007) Opportunity lost: how law school disappoints law students, the public, and the legal profession, California Western Law Review, 44, pp. 219-255.

Editorial (1992) Score one for Dan Quayle: too many lawyers, suits, Deseret Nerws, 21 July.

Federation of State Medical Boards (2012) For the public. Available at: http://fsmb.org/ua.html, accessed 20 July 2012.

Green, B.A. (2009) ABA ethics reform from 'MDP' to '20/20': some cautionary reflections, fournal of the Professional Lawyer, 2009, pp. 1-12.

Greenbaum, M. (2010) No more room at the bench, Los Angeles Times, 8 January.

Grigg, L. (1998) The Mandatory Continuing Legal Education (MCLE) debate: is it improving lawyer competence or just busy work?, Bringham Young Law Review, 12, pp. 417-434.

Hadfield, G.J. (2000) The price of law: how the market for lawyers distorts the justice system, Michigan Law Review, 98, pp. 953-1006.

Harper, S.J. (2011) Suffering in silence; as unhappy as the respondents to our midlevel survey sound, their plight could be worse. Just ask some of their fellow law school graduates, American Lawyer, 82, published online by Lexis, document ID: 1202511938585.

Henderson, W.D. \& Zahorsky, R.M. (2011) Paradigm shift, American Bar Association fournal, 97, pp. 40-47.

Jarvis, R.M. (1996) An anecdotal history of the bar exam, Georgetown fournal of Legal Ethics, 9, pp. 359-412.

MacCrate Report (1992) Legal Education and Professional Development: An Educational Continuum, (American Bar Association, Section on Legal Education and Admissions to the Bar), p. 104.

Maguire Shultz, M. \& Zedeck, S. (2009) Final Report - Identification, Development and Validation of Predictors for Successful Lawyering, Available at: http://ssrn.com/abstract=1353554, accessed 21 February 2013.

McKay, R.B. (1984) The future of professional independence, The Lawyer's Professional Independence: Present Threats/Future Challenges, (Chicago, American Bar Association), pp. 39-52.

Morgan, T.D. (2010) The Vanishing American Lawyer (New York, Oxford University Press).

Nakazato, M., Ramseyer, J.M. \& Rasmusen, E.B. (2006) The Industrial Organization of the Japanese Bar: Levels and Determinants of Attorney Income, Center for Law, Econonomics and Business, Working Paper No. 559, 2006.

National Conference of Bar Examiners (2012) Bar Examination and Admission Statistics, Available at: http://www.ncbex.org/publications/statistics/, accessed 1 December 2012.

Podgers, J. (2011) The state of the union: the nation's lawyer population continues to grow - barley, American Bar Association fournal, 97(7), p. 58.

Press, A. (2011) The law school troubles; it's been another dreadful year for the public image of law schools, American Lawyer, September, 126, published online by Lexis, document ID: 1202511941503.

Rhode, D.L. (2000) In the Interests of fustice: Reforming the Legal Profession (New York, Oxford University Press).

Rhode, D.L. (2005) Pro Bono in Principle and Practice: Public Service and the Professions (Stanford, Stanford University Press). 
Sander, R.N. \& Williams, E.D. (1989) Why are there so many lawyers? Perspectives on a turbulent market, Law E Social Inquiry, 12(3), pp. 431-479.

Segal, D. (2011a) What they don't teach law students: lawyering, New York Times, 19 November. Available at: http://www.nytimes.com/2011/11/20/business/after-law-school-associates-learn-to-belawyers.html?pagewanted=all, accessed 20 June 2012 .

Segal, D. (2011b) Law school economics: ka-ching!, New York Times, 16 July. Available at: http://www. nytimes.com/2011/07/17/business/law-school-economics-job-market-weakens-tuition-rises.html?scp= $1 \&$ sq=law\%20school, accessed 20 June 2012.

Segal, D. (2011c) Is law school a losing game?, New York Times, 8 January. Available at: http://www. nytimes.com/2011/01/09/business/09law.html?pagewanted=all, accessed 20 June 2012.

Segal, D. (2012) For 2nd year, a sharp drop in law school entrance tests, New York Times, 19 March. Available at: http://www.nytimes.com/2012/03/20/business/for-lsat-sharp-drop-in-popularity-forsecond-year.html, accessed 20 June 2012.

Shaer, M. (2012) The case(s) against law school, New York Magazine, 4 March. Available at: http:// nymag.com/news/features/law-schools-2012-3/, accessed 20 July 2012.

Sloan, K. (2011a) Law school? Who needs it? "Reading the law" remains an option, but carries its own challenges, National Law fournal, 5 December.

Sloan, K. (2011b) ABA faces diversity dilemma with proposed change to law school standards, lawjobs.com, 22 July. Available at: http://www.law.com/jsp/article.jsp?id=1202504348774\&slreturn=1, accessed 20 June 2012.

Tamanaha, B.Z. (2012) Failing Law Schools (Chicago, University of Chicago Press).

US Government Accountability Office (2009) Higher Education: Issues Related to Law School Cost and Access (US, USGAO).

Walsh, L.E. (2003) The Gift of Insecurity: A Lawyer's Life (Chicago, American Bar Association).

Wilkins, D.B. (1992) Who should regulate lawyers?, Harvard Law Review, 105, pp. 801-873.

Winston, C.M. \& Crandall, R.W. (2011) First Thing We Do, Let's Deregulate All the Lawyers (Washington, DC, Brookings Institute Press).

Wolfram, C.W. (1986) Modern Legal Ethics (St. Paul, MN West Publishing). 